\title{
1. Whither modern business incubation? Definitions, evolution, theory, and evaluation ${ }^{1}$ \\ Sarfraz A. Mian
}

\section{BACKGROUND AND INTRODUCTION}

As chronicled by Adkins (2002), the first business incubator started in early 1959 in Batavia, New York, when Joseph Mancuso acquired an abandoned 850000 square foot factory from Massey-Ferguson. Due to the closure of the factory, 2,000 people lost their jobs, and Mancuso undertook the task of trying to reduce unemployment by filling the old factory premises with small businesses; this came to be known as Batavia Industrial Center. For a fee, Mancuso offered office space, shared service, help with financing, and some business coaching. Among the first tenants was a company that developed an egg hatchery to artificially produce chickens, which led to the facility being jokingly referred to as the 'incubator'. Shortly, thereafter in 1964, University City Science Center (UCSC), the nation's first urban research park and incubator was set up in downtown Philadelphia, in collaboration with a consortium of the area's 28 academic institutions. The UCSC accepted startup firms, providing them with supportive environment throughout the 1970s and beyond, under the leadership of Randall Whaley. The National Business Incubation Association (NBIA) recognized Mancuso and Whaley as incubation industry founders by honoring them with an award in 1998. They were credited for the initiation and firmly rooting of the business incubation concept respectively through formal programs where new companies in the startup phase were supported to improve their chances of success (Adkins 2002; Bruneel et al. 2012). Application of the concept, however, did not become widespread in the country until well into the 1970s and 1980s.

The origin of the technology-oriented business incubation support is generally linked to universities' involvement in technology development and commercialization efforts undertaken in the US in the post-WWII period, the pioneering example of which is the Stanford Research Park near Silicon Valley in California, which was established in 1951. Affiliated with Stanford University, the Park housed R\&D units of large technology firms, university spin-offs, and promising startups, specific to the contemporary research park model.

Second, are the concerted efforts at MIT during the post-WWII period, where its president Karl Compton led the drive of university technology transfer through spin-offs to benefit from the commercial use of prior military developments. During this period, the support of spin-offs predominantly originated from MIT's research labs, many of which were located in MIT owned facilities in the surrounding areas, by early venture capital firms such as the American Research and Development (ARD) corporation, the 'brainchild' of Compton. ARD offered business advice and funds to these spin-offs, which shows that MIT had a key role in seeding the technology-based firm creation; some of these startups were later located to the Boston Route 128 (Roberts 1991). This, apparently, was a regionally distributed model of technology business incubation. 
Third, account is that of the underground projects in aerospace firms in Los Angeles, California during the same period. These auxiliary projects, so-called 'skunkworks' were set up to house innovative projects that did not fit with the main purpose of the parent firm, a concept that some other companies and industries also copied, and then introduced to universities; it was later dubbed as an 'incubator', a means of encouraging professors to start technology-related projects leading to innovative new firms (Lamine et al. 2018). The Rensselaer Polytechnic Institute (RPI) is another key player to the transition of industry 'skunkworks' into a successful university technology incubator and a research park in early 1980s (Etzkowitz, Chapter 3 in this Handbook).

These US efforts spread over a quarter century laid the foundation of technology-based business incubation industry, which is closely linked with the 'entrepreneurial' research universities.

Parallel to these initiatives, various scholars (Birch 1979; Kirchhoff 1994) highlighted the importance of innovative small firms in both employment and economic growth, which provided the impetus to the burgeoning incubation industry pioneered by the aforementioned US efforts prior to the 1980s.

Subsequently, business incubators were introduced in Europe in the 1980s and the European Union launched a network of incubators known as the European Business Network (EBN) in 1984. The oldest incubator in the UK, St John's Innovation Centre in Cambridge, was established in 1987 (Bone et al. 2017); some earlier incubation initiatives have also been reported in other parts of Western Europe (ibid.).

As stated above, research/science/technology parks took off earlier during the 1950s in the US and then several European countries started establishing them in the late 1960s; in the subsequent decades they became popular worldwide (Albahari, Chapter 5 in this Handbook).

Business/startup accelerator, the latest major incubation model, appeared in 2005 in the US in the form of Y-Combinator. One program was located in Cambridge, Massachusetts, adjacent to the MIT campus and another in the Silicon Valley, California. In 2009, YCombinator consolidated by closing its Cambridge program and expanding its operation in the Silicon Valley. Other popular for-profit startup/seed acceleration programs include TechStars established in Colorado in 2006, and later expanded worldwide. These models (known by different names: startup factory, startup foundry, or a venture studio) became popular between 2008-2013. Today there are well over 100 known programs across the world, about half of which are located in Europe. Accelerators are generally tied to the lean startup model and predominantly support digital startups (Van hove et al., Chapter 4 in this Handbook).

The Venture Development Organization (VDO) is another incubation support model popular in the US. VDOs are equipped with investment capital as well as business mentors' network without the existence of a physical incubator space. They provide a comprehensive way to address both the business support and capital needs of startups throughout the high-risk seed and early stages (LaVigne, Chapter 10 in this Handbook).

Research shows that today thousands of incubation programs with a varied set of models, developed and refined over the past more than six decades, are in use globally (Hausberg and Korreck 2020; Klofsten et al. 2020; Messeghem and Sammut 2014). The popularity of the concept has not waned, and the new and improved incubation models 
have appeared, and are gaining attention (Mian et al. 2016). The modern incubation approach is operationalized through numerous incubator mechanisms and their models such as business incubators, technology incubators, innovation centers, accelerators, science parks, co-working and maker spaces, startup garages, and some virtual models, etc. $^{2}$

Business incubators are considered to be promising policy mechanisms that support entrepreneurial growth by nurturing new firms through their developmental lifecycle. They are viewed as preferred tools by policymakers for promoting the development of technology-based and growth-oriented firms (Mian et al. 2016; Galbraith et al. 2019). Incubation programs are generally established through public-private collaborations among universities, industry, and all levels of government, and they facilitate technology transfer and diffusion of products, by incubating new and novel ideas into ventures thereby developing regional economies through new firms (EU 2010; Mian 2014a; 2014b).

It is well understood that innovative startups can create and shape new industries and generate considerable economic and societal benefits, therefore, a variety of such policy initiatives are aimed at promoting the establishment, growth, and impact of innovative startups (Audretsch et al. 2020). While innovative firms lay the foundation for new wealthcreating industries, the race to develop appropriate policy and program mechanisms to help create and develop regions and ecosystems that enable new technology startups, continue to pose challenges for policymakers seeking relevance in their planned interventions (Mian 2011). This warrants policy that places an emphasis on the effective exploitation of new knowledge and the development of innovative technologies that are rapidly commercialized for economic gain (Mian et al. 2016). Consequently, scholars, policymakers, and practitioners increasingly recognize the importance of seeding and accelerating entrepreneurship and technological innovation through strategic entrepreneurial initiatives, by the provision of mechanisms and resources that support new ventures. So, there is a tremendous value in understanding the programs and mechanisms that make incubation more effective.

To better understand modern business incubation and acceleration and provide a state-of-the-art overview of various mechanisms and models, the key questions asked are: How do we define incubation mechanisms? Where do we stand in terms of understanding the incubation process and developing theory? How have various incubation models emerged over the past several decades? How to assess incubation programs to develop best practice models? What is the incubation industry's future direction?

\section{DEFINING INCUBATION MECHANISMS}

Scholars have identified numerous definitions of business incubation and incubator mechanisms which vary considerably in terms of their designs, functions, and scope of activities (Hausberg and Korreck, Chapter 2 in this volume), and some of which are very broad (Etzkowitz, Chapter 3 in this Handbook). Understanding the boundaries of business incubation and dealing with the heterogeneity of incubator-incubation definitions has been a challenge in the incubation literature and is also reflected in variations in definitions put forward by the professional associations (Mian 2014a). Therefore, articulating clearer 
definitions of various incubator mechanisms and their models to promote research and refine practice is imperative for the growth and professionalization of the field.

In their recent work on the heterogeneity of incubator-incubation definitions, Al-Ayyash et al. (2020) have reviewed academic as well as practitioner definitions reported in 61 publications. The findings show that there are three thematic streams: The incubator purpose, its target firms, and its business model, along with the sub-themes of mediation and resource provision. Citing Puranam et al. (2014) on new forms of organizing, the authors recommend the use of a comprehensive definition which covers all these themes; this has also been advocated by several other incubation scholars (Smilor and Gill 1986; Mian 1997; Hackett and Dilts 2004; Grimaldi and Grandi 2005).

The International Business Innovation Association, world's largest professional association representing the field of incubation defines business incubation as follows (iNBIA 2017):

Business incubation is a support process that accelerates the successful development of startup and fledgling companies by providing entrepreneurs with an array of targeted resources and services. These services are usually developed or orchestrated by incubator management and offered both in the business incubator and through its network of contacts. A business incubator's main goal is to produce successful firms that will leave the program financially viable and freestanding. These incubator graduates have the potential to create jobs, revitalize neighborhoods, commercialize new technologies, and strengthen local and national economies.

Smilor and Gill (1986) first articulated the concept of technology incubators from a scholarly perspective, as offering a link between: 'technology, know-how, entrepreneurial talent, and capital'. They are generally property-based initiatives providing tenant firms with a portfolio of new venture support infrastructure, including: business services, networking (Bergek and Norrman 2008), access to professional services (Sherman and Chappell 1998), university resources and access to capital (Mian 1996). The intent is to help startups by providing enabling linkages to help the new businesses survive, scale-up, and grow.

According to Hochberg (2016), the new incubator mechanism, the accelerator, is

a fixed-term, cohort-based model providing education and mentoring for startup founders. Additionally, exposing new venture teams to former entrepreneurs, venture capitalists, angel investors, and corporate executives. Thereby, preparing founders for public pitch events in which graduates pitch their businesses to large groups of potential investors. In practice, accelerator programs combine distinct services and functions that are difficult and costly for an entrepreneur to find and obtain.

Accelerator programs have since been widely adopted by both public and private sponsors (Cohen et al. 2018: Drori and Wright 2019).

According to Link and Scott (2015), the science park is set up as a public-private partnership and the current definition by the International Association of Science Parks (IASP), which is most often used by academia is

an organization managed by specialized professionals, whose main aim is to increase the wealth of its community by promoting the culture of innovation and the competitiveness of its associated businesses and knowledge-based institutions. To enable these goals to be met, a science park stimulates and manages the flow of knowledge and technology among universities, R\&D 


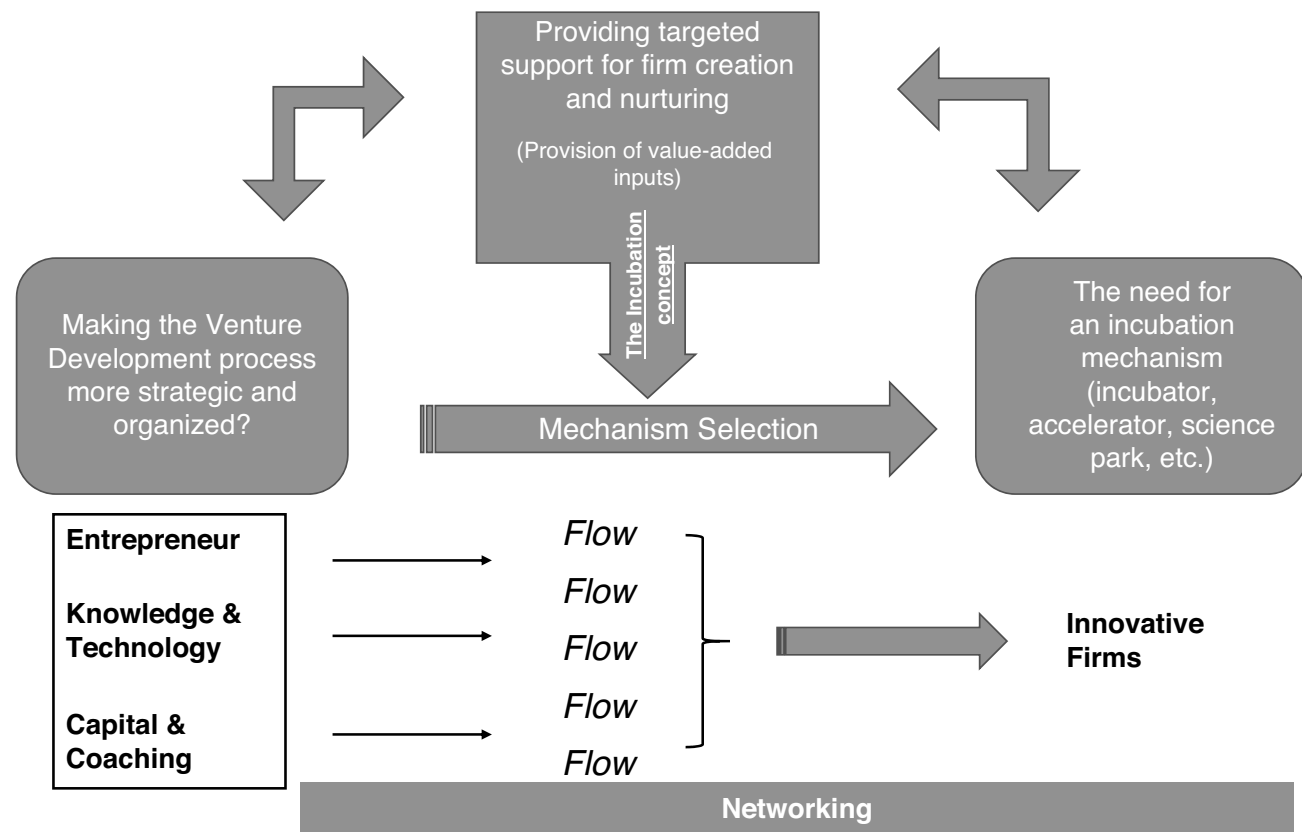

Source: Author's creation based on his interpretation of the literature.

\section{Figure 1.1 Conceptualizing the incubation function}

institutions, companies and markets; it facilitates the creation and growth of innovation-based companies through incubation and spin-off processes; and provides other value-added services together with high-quality space and facilities.

In some countries, such as the US, the term research park is more common, and they aim to attract units of existing large firms as well (AURP 2018). ${ }^{3}$

Conceptualizing business incubation as an umbrella term for new venture development programs, and emphasizing process as well the provision of value-added services, I define incubation as an organized function to facilitate and steer venture creation and growth for client entrepreneurs, with a strategic perspective (Audretsch et al. 2015). It happens in incubators, accelerators, science parks, and other similar venture support programs (Dee et al. 2015). Figure 1.1 articulates this view by conceptualizing the incubation function with the goal, processes, activities; and client incubatees opting for the appropriate mechanism/model which better serves their needs. Based on the findings of Al-Ayyash et al. (2020), a comprehensive definition of a model is proposed. This means that to be considered as an incubator/accelerator/science park, the program must have a purpose or mission, know its target firms, and have a well-defined business model with the value-adding services package. Since incubators and science parks are generally property-based, they are more likely to offer mediation, buffering, and bridging resource provisions (Amezcua et al. 2013). In this way, the tenants address the resource acquisition challenges by overcoming their weak network problems and draw from the incubator's 
entrepreneurial ecosystem through meeting, mating, and intermediating (Van Rijnsoever 2020).

Table 1.1 provides a comparison of the value-add inputs/services of the three major incubation models, incubator, accelerator, and science park. It shows an overlap in several services provided by these models. For practical purposes, the 'length of support' is a function of any facility's entry/exit policy and the exact timeline is difficult to draw. For example, in a science park/technology incubator setting, research and technologyoriented firms such as biotechnology, may avail longer tenancies, so actual practices may vary depending upon the circumstances and client needs. Similarly, accelerators may also allow longer/shorter support periods depending upon client requirements.

The startup cycle of the typical technology business is depicted in Figure 1.2, which allows better understanding of the relationship of each incubator mechanism to the incubation support process (EU 2002). While some comprehensive models of science parks support the entire innovation continuum - germination, incubation, and consolidation most facilities do not. This heterogeneity leads to inconsistent definitions, criteria for evaluating effectiveness, determination of how much value incubator mechanisms add, and identification of the key success factors (Albort-Morant and Ribeiro-Soriano 2016). As pointed out earlier, these variations hamper the development of a unified conceptual framework in business incubation research.

\section{THE EVOLUTION OF INCUBATION MECHANISMS AND THEIR MODELS}

As stated earlier, with the inception of the business incubation industry in the 1950s, the concept took root in the US. There was a modest growth in the number of incubation facilities over the next couple of decades until we witnessed a policy change at the federal and state levels during the 1980s and 1990s when support for indigenous technology development and a broader support for innovation and diffusion into the national economy was encouraged (Mian 2011). As a result, many US universities established research/ science park and incubator programs through public-private partnerships, and many of these university-related incubators continue to be models of best practice (Mian et al. 2016; Link and Scott 2003). This helped solidify the acceptance of business incubation, which had since undergone considerable growth over the past decades, with significant model enhancements, post the 1980s.

As Mian et al. (2016) outlined, ${ }^{4}$ in the US, the first wave (till 1980) of incubator programs was aimed at economic restructuring and job creation. These programs provided affordable space and shared services. As shown in Figure 1.3, by 1980 there were 31 research parks and 11 business incubators in the United States. By 2000, their numbers rose to 750 incubators and 159 research parks. The research/science park model evolved from a stand-alone technology garden to a networked commercialization enabler. The second and third waves of incubation models offered a more complete menu of value-adding services, including counseling, skills enhancement, and networking. Since the new millennium, research parks have moved toward a mixed-use science park equipped with a technology incubator. In some cases, the facility cohabits with commercial and residential facilities. According to the available data, there are over 1,400 incubators in the United States (iNBIA 2017). 


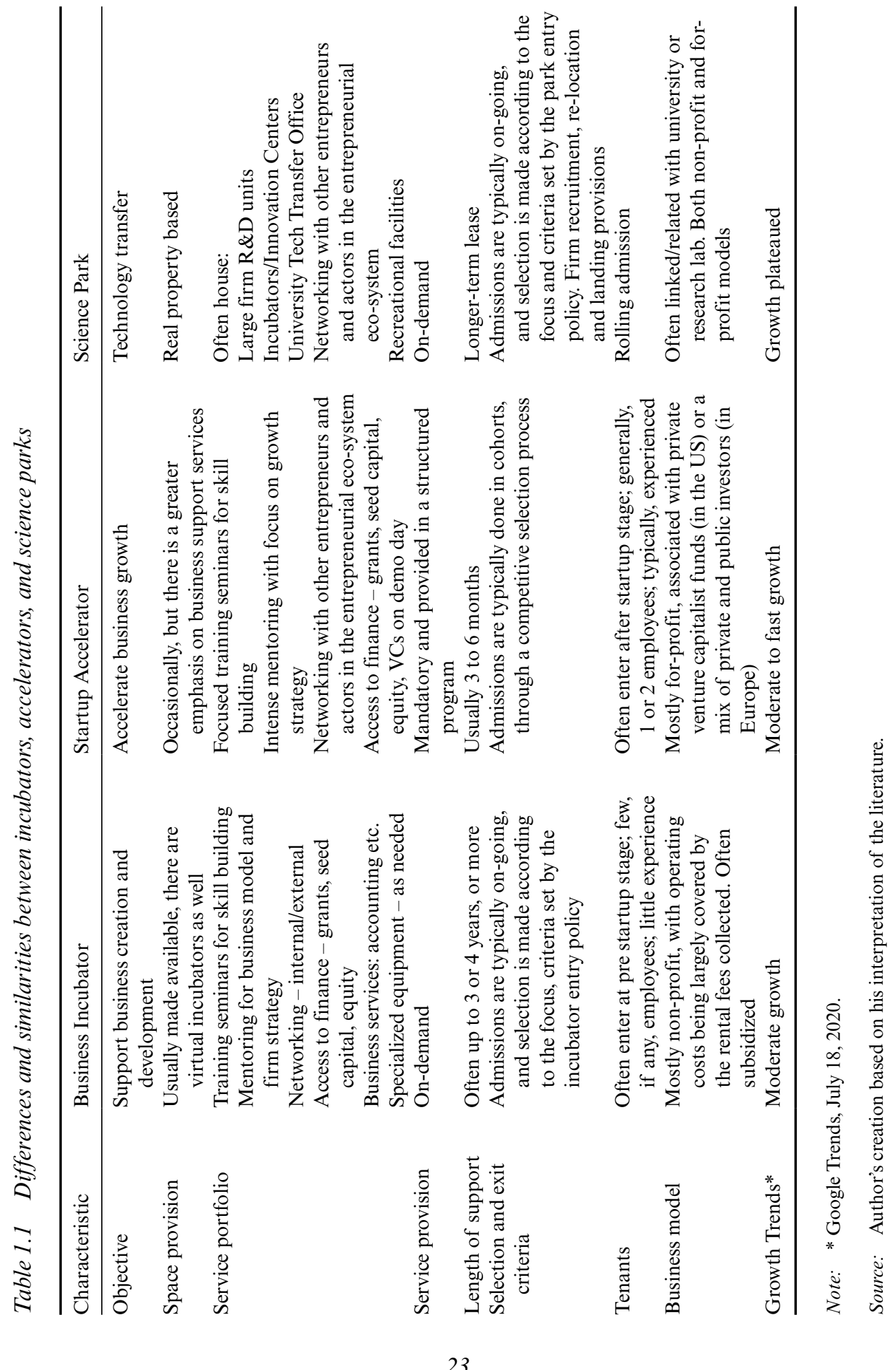




\begin{tabular}{|l|l|l|}
\hline $\begin{array}{l}\text { PHASE 1: Pre- } \\
\text { Incubation/Idea } \\
\text { development }\end{array}$ & $\begin{array}{l}\text { PHASE 2: Incubation and } \\
\text { acceleration }\end{array}$ & $\begin{array}{l}\text { PHASE 3: Post-Incubation } \\
\text { consolidation and Growth }\end{array}$ \\
\hline
\end{tabular}

Business Incubator/Accelerator

German Innovation Center/Technology Incubator

Science Park/Technology Park/Research Park

French Research/Academic

Incubator
French Pépinières and

Hatcheries
French Technopolis

\section{Virtual Incubator/Accelerator}

Source: Adapted from EU (2002).

Figure 1.2 Incubation mechanisms and their roles in various phases of the firm development

Several factors contributed to the rapid growth of incubation programs in the US (Adkins 2002): (1) advocacy and support of the United States Small Business Administration (SBA); (2) the State of Pennsylvania's pioneering Ben Franklin Technology Development Program; and (3) Control Data Corporation funding incubators in several American cities. Recognition of the apparent failure of state policies for attracting investment by large multinational firms, and the work of researchers such as Birch (1979) and Kirchhoff (1994) emphasizing the importance of startups and small firms in terms of job growth and contribution of growth to the national economy, helped catalyze the country's incubation movement (Mian and Plosila 2011).

Following the success of early incubators in the US there has been extensive worldwide activity in establishing these novel tools of economic development, and parallel efforts were underway in various European nations to benefit from this novel approach to the innovative firm development (EU 2010; Autio and Klofsten 1998; Bone et al. 2017). Information collected from the national and regional professional associations for incubators and their web sources indicate the latest available figures of existing programs in: ${ }^{5}$ Germany 300 (BVIZ 2019); UK 207 (Bone et al. 2017); France 113 (RETIS 2010); Sweden 40 (SISP 2019); Canada 120 (CABI 2012); Brazil 363 (ANPROTEC 2019); China 670, Japan 190, Singapore 120, Malaysia 110, Australia 80 (AABI 2009); African continent 50+ (iNBIA 2017); India 276 (IIM 2019); Pakistan 65 (IBA 2019). Globally there are about 7,000 incubator programs worldwide, one-third of which are technology-oriented (iNBIA 2017). 


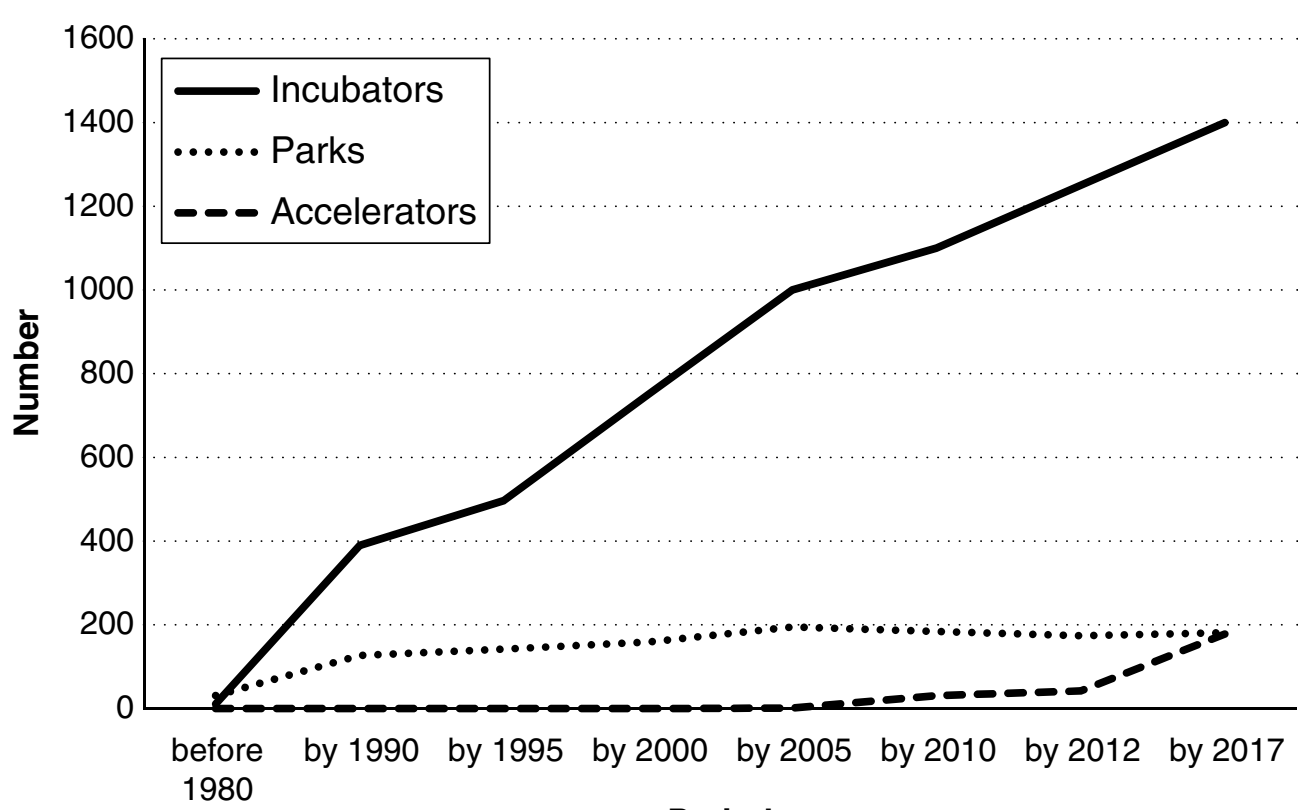

Period

Sources: $\quad$ Mian et al. 2016; iNBIA 2017; AURP 2018; Hathaway 2016.

Figure 1.3 US incubation mechanisms' growth

Following the US lead, the early science parks in Europe were Sophia Antipolis (1969) in France and Cambridge Science Park (1970) in the UK. By the end of the 1970s, around 50 science parks were established in over a dozen European countries, including the UK, France, Sweden, Germany, Belgium, Japan, Korea, and Taiwan (Mian et al. 2016). In 2017, Science and Technology Parks were globally distributed with more than 500 facilities $^{6}$, with the top ten participants: China 80, United States 72, UK 63, France 60, Finland 24, Korea 18, Iran 16, Canada 13, Sweden 12, and Australia 9 (UNESCO 2018). Science parks are generally supported by universities, local or national governments, which also provide financial support; in the 1990s the European Union became directly involved in supporting science parks (EU 2013). Incubators and science parks have come closer to each other over the past decade, as many of them are co-located, with 98 percent of the science parks reported having incubator facilities; in fact some science parks operate as de facto incubators (IASP 2015).

In the 1990s, a new incubation model emerged - the Internet-based virtual incubation model that supports new venture growth, particularly in specialized ventures such as Information Communications Technology (ICT) startups. For example, Idealab (founded in 1996) as a for-profit Internet incubator grew rapidly but waned within months of the April 2000 NASDAQ technology stock crash (iNBIA 2017). Additionally, specialized brick-and-mortar incubators in areas such as biotechnology and aerospace are integrated into science parks and grow well (ibid.).

The digital economy gave rise to a new form of incubation mechanism, the accelerator. 
The first seed accelerator was Y-Combinator, started in Cambridge, Massachusetts, in 2005, and then later moved to Silicon Valley (Drori and Wright 2019). It was followed by TechStars (in 2006), Seed-camp (in 2007), Startup-bootcamp (in 2010), Tech Wildcatters (in 2011), several accelerators of SOSV (a multi-stage VC investor), and Boomtown Boulder (2014) (Gilani and Gianluca 2011). They aim at building several companies in succession from internal as well as external ideas and focus on providing human capital, business and financial support, and access to networking.

In Europe, the first accelerator program was started in 2009 in Denmark, followed shortly after in 2012 in Estonia (Barrehag et al. 2012). Since 2010 there has been a substantial growth of Corporate Accelerator programs, which are sponsored by established organizations but follow similar principles (Heinemann 2015).

In a study, Hathaway (2016) identified 172 US accelerator programs; and researchers estimate that there are up to 2,000 such programs globally (Cohen et al. 2019). Today, Europe leads with the most accelerator programs and resisted the North American trend of slower accelerator growth since 2012. The accelerator industry has also been expanding rapidly in Latin America and Asia, where a mix of private and public capital is fueling a surge in startups and accelerators. According to the most recent Global Accelerator Report 2016 (Rose and Grof 2017), in the year 2015, \$192 million were invested into more than 8,836 startups in 837 accelerator facilities across five world regions, the United States and Canada, Europe, Latin America, Asia and Oceania, and the Middle East. Interestingly, while Europe's total investment is a little less than half that of the US and Canada, its accelerators have invested in a nearly equal number of startups, with each region (US-Canada and Europe) representing about one-third of the total global number of accelerated startups. Latin American accelerators' share is about 15 percent, Asia and Oceania's 14.7 percent and the Middle East's 7.5 percent of the global total (ibid.).

Figure 1.4 depicts how over the last four decades three generations of incubation mechanisms have emerged. Their model enhancements in terms of value-added inputs and integration into the surrounding entrepreneurial ecosystem are shown across various phases along with the incubator mechanism/model type, services offered, the rationale, and examples from the US (Mian et al. 2020; Mian et al. 2016; Bruneel et al. 2012; Messeghem et al. 2017; Clarysse et al. 2005). The mechanism type, services offered, support rationale, and the example provide further details in understanding the array of programs that provide incubation support in the US and beyond. This shows how the industry has emerged and matured, gaining recognition.

The first effort to categorize traditional incubation mechanisms was along the degree of management support versus technological level of the mechanism (EU 2002), which allowed distinguishing among general business incubators, technology incubators/ innovation centers, and science and technology parks. The other approaches include (1) based on incubator clients from sectoral/industry focus; (2) based on incubator facility's organizational structure, with wall or brick-and-mortar, without a wall or virtual; and (3) based on their sponsorship type, privately-run for-profit or government-supported non-profit incubators (Mian 2014a).

In a study of accelerator programs in major European capitals, Pauwels et al. (2016) categorized accelerators into three categories based on design thinking as: ecosystem builder sponsored by corporations, deal-flow maker sponsored by investors, and welfare stimulator sponsored by governmental bodies. 


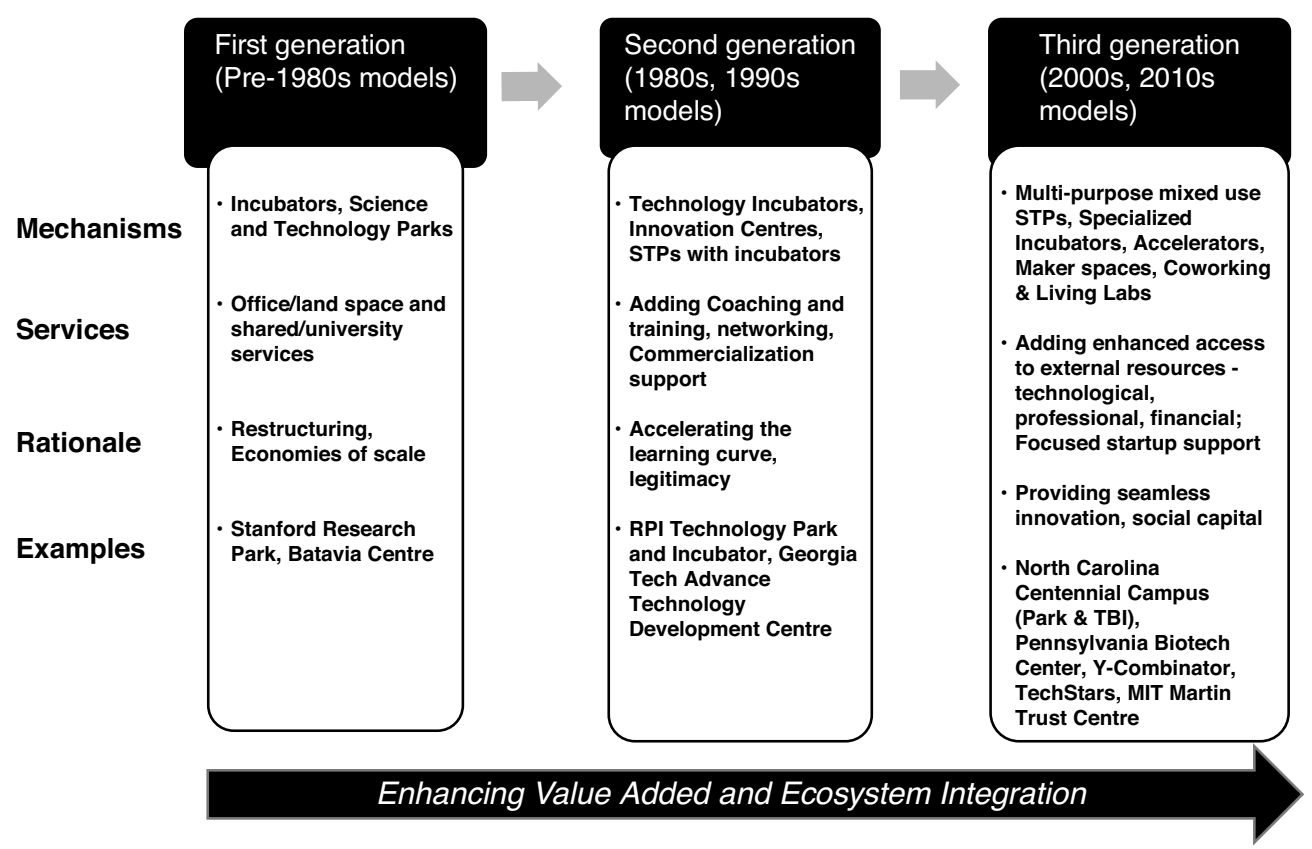

Figure 1.4 Evolution of incubation mechanisms' value proposition

To classify the wide spectrum of the innovation and entrepreneurship intermediaries, Figlioli et al. (2017) proposed two levels of aggregation: The first level includes mechanisms that offer support with a broader mission in coordinating their activities. This includes science and technology parks, technopoles, innovation hubs, etc. Here, the key design variables are location, infrastructure, facility management and governance, technology transfer programs and services offered. The second level comprises mechanisms that provide resource inputs to mitigate certain innovation system gaps, with a more focused mission. These include incubators, accelerators, co-working, and maker spaces. At this level important considerations are value proposition, target customers, organizational policies, and services offered. Despite the diversity in their missions/objectives at both levels, there are several programmatic and service overlaps within these types.

\section{THEORETICAL APPROACHES TO UNDERSTAND THE INCUBATION PROCESS}

Van de Ven (1989) reminds us that: 'to advance any scientific discipline it is important to have a well-developed theory, as it guides research and refines practice'. It may be noted here, that the bulk of the early incubation literature is considered fragmented and anecdotal with a focus on success stories and outcomes, and much of the research was best described as theoretical (Hackett and Dilts 2004; Mian 2011). This had been a problem for incubation researchers, as Phan et al. (2005) posited that these shortcomings coupled with the lack of systematic longitudinal studies make the development of a generalizable 


\section{Handbook of research on business and technology incubation and acceleration}

theory challenging. The authors assert that the generalizable theory (in this case) may not be possible due to the idiosyncrasies of science parks, incubators (and accelerators) in relation to geographic, political, social, and economic systems. Hence, one of the major challenges for research on business and technology incubators is the lack of a unified theory.

Some recent studies (Mian et al. 2016; Hausberg and Korreck 2020) have attempted to fill this gap by synthesizing the extant literature with limited success. In the absence of a unified theory, researchers have derived various theoretical lenses used to explain business incubation and study the incubation process. Table 1.2 presents a summary of these efforts along with the authors who used and/or studied the use of these theoretical lenses. The breadth of disciplinary sources illustrates how incubation theory development spans various disciplines. The use of a wide variety of approaches and theoretical lenses show the diverse and multidisciplinary nature of the incubation process.

It may be noted here that the earlier First-Generation 'configurational' incubation models were considered deficient in providing the critical process-oriented incubation support to their incubatees (Autio and Klofsten 1998). When looking at the incubation process from the perspective of client firms' needs, it can be argued that these initial incubation settings remained substantially undeveloped, which needed supplemental training programs often set up at universities to address this gap (Klofsten et al. 2020).

The advance of the Open Innovation view (Chesbrough 2017) and its application to the role of innovation and entrepreneurship intermediaries such as incubators, provides empirical evidence and hence the rationale for support of incubation programs (Clausen and Rasmussen 2011). Furthermore, the Third-Generation incubation models, which emphasize the importance of internal and external networking and value addition of social capital, clearly show the advantages of incubation to support firm growth particularly for mid-stage startup companies. Petrucci (2018) asserts that 'this novel (networking) arrangement (offered by the Third-Generation models) consist of an unexpected evolution of the initial incubation settings which substantially change according to the opportunities that emerge in the (already existing) networks of incubatees'.

The scope of this chapter does not allow a detailed discussion of the use of each theoretical lens, for which the reader is directed toward the work of respective authors quoted in Table 1.2; some of which is included in this Handbook.

In summary, despite the lack of a unified theory, a synthesis of the use of these theoretical lenses show that Open Innovation and Social Capital or Social Network Theory increasingly complement the Resource-Based View as frameworks to understand business incubation (Hausberg and Korreck 2020). Similarly, the use of Market Failure View has long been advocated by scholars to justify providing incubation support particularly for academic startups where inventors generally lack market knowledge (Plosila and Allen 1985; Bøllingtoft and Ulhøi 2005; Soetanto and Jack 2016). The Structural Contingency lens is most often the rationale used for the adaptation of incubation programs to fit with the contextual requirement of an entrepreneurial ecosystem (Mian et al. 2016; Lamine et al. 2017). This is especially the case in resource-constrained regions (see Chapters 11 to 20 in this Handbook). 
Table 1.2 Theoretical lenses employed to study the business incubation process

Theoretical Lens Employed
Market Failure View of Venture Creation - The incubator
compensates for perceived failures or imperfections in the
marketplace to counter the problems caused by an inefficient
allocation of resources
Resource Based View - The incubator as an organization
awarding a stock of tangible and intangible resources to client
firms that result in development of the client firms

Stakeholders' View - Incubators act as a bridging mechanism to implement the interests of key regional stakeholders (Triple Helix, Quadruple Helix)

Structural Contingency Theory - Incubation mechanisms are configured to fit the external environment and be tailored to local needs and norms

Social Capital/Network Theory - Incubation mechanism as a system for increasing client firms' internal and external network density

Real Options View - Client firms are supported from a pool of available options through selection criteria based on fit with incubator strategy

Dyadic Theory - An interdependent co-production dyad where incubation assistance is co-produced by the incubator management and tenant entrepreneur

Institutional Theory - The incubator's support mechanism rules and contracts offer a more structured approach to reduce uncertainty and risk and accelerate the process

Mechanisms-Driven Theory - The incubator implements its own internal policies through an understanding of the relations that are value laden and context-based within the incubator organization

Virtual Incubation View - The Incubator offers knowledge brokering and information dissemination in the market space of ideas to develop innovative ventures

Open Innovation View - This lens helps to understand particularly the modern corporate incubator with its focused absorptive capacity from the perspective of its corporate sponsor

Absorptive Capacity - This lens can help to explain the resources that a corporate incubator/accelerate can leverage from their sponsor(s)
Authors

Plosila and Allen (1985);

Bøllingtoft and Ulhøi (2005)

McAdam and McAdam (2008); Patton et al. (2009); Todorovic and Moenter (2010); Mian et al. (2016);

Autio and Klofsten (1998)

Mian (1997); Corona et al. (2006); Etzkowitz (2002);

Cadorin et al. (2019)

Ketchen et al. (1993); Phan et al. (2005); Klofsten et al. (2020)

Tötterman and Sten (2005);

Hansen et al. (2000)

Hackett and Dilts (2004)

Rice (2002); Warren et al. (2009)

Guerrero and Urbano (2012);

Phan et al. (2005)

Ahmad (2014);

Bergek and Norrman (2008)

Nowak and Grantham (2000);

Gans and Stern (2003)

Weiblen and Chesbrough (2015); Hausberg and Korreck (2020)

Cohen and Lavinthal, (1990);

Hausberg and Korreck (2020)

Source: Mian et al. (2016) with adaptations. 


\section{INCUBATOR PROGRAM EVALUATION AND SPATIAL CONTEXT}

Experts and scholars have often underlined the importance of systematic evaluation of incubation programs for a variety of reasons: for management and administrative purposes, to assess the appropriateness of program changes, to identify ways to improve the delivery of interventions, or to meet the accountability requirements of funding groups. The three most researched areas in incubation are impact, management, and assessment, which lead to benchmarking for best practices (Mian et al. 2016).

Consequently, the evaluation of an incubation program or performance assessment has been a major topic of incubation research and several studies have attempted to address this need, with a varying degree of success (Mian 1997; Hackett and Dilts 2004; Voisey et al. 2006; Siegel et al. 2003; Torun et al. 2018; Barbero et al. 2012; EU 2002; Messeghem et al. 2017). In their recent work, Hausberg and Korreck (2020) assert that the available evaluation studies are heterogeneous, use different methodological approaches and focus on different measures and units of analysis such as incubatees, incubators, and the region. They further point out the difficulties in getting reliable firm data from entrepreneurs within and outside incubators to conduct any meaningful studies including comparisons with non-incubate firms. Looking from a practitioner perspective, Voisey et al. (2006) provided an assessment framework of different soft and hard measures of incubator program performance, using data collected from the incubated firm as well as the incubator, which emphasize both perspectives. Torun et al. (2018) systematically reviewed the incubator evaluation literature using Web of Science data comprising of 138 performance assessment studies of which 42 studies developed Key Performance Indicators (KPIs) and 14 had clear benchmarks. From these 14 studies, seven most comprehensive and professionally oriented studies were selected to develop a framework consisting of 33 aggregated KPIs. These selected KPIs are intended to measure the incubation program performance at incubate-incubator and community levels. The work provides a comprehensive framework to benchmark incubator programs that pursue best practices for continuous improvement.

Judging the impact of a spatial/geographical context, in their study to measure the influence of a challenging regional context, Harper-Anderson and Lewis (2017) found that the incubator quality variables have a stronger causal influence on successful incubation outcomes than regional capacity variables, showing that overall incubator quality matters more. Thus, strong incubator programs and the presence of a source of new knowledge and human capital such as a university or research institute may compensate for the deficiencies in regional innovative capacity to promote entrepreneurship (Vedovello 1997). In a study of the North American innovation regions, Mian et al. (2020) have proposed a framework for the spatial placement of incubators and science parks based on their models' strength and the regional resources available within each context, emphasizing a better match. Similarly, Goswami et al. (2018) have shown the potential of accelerator programs in building an entrepreneurship ecosystem in an emerging economy context.

Schwartz (2011) asserts that evaluating an incubation program from the incubate firms' perspective is equally critical as it is possible that firms that spent a number of years in an incubator may be lacking survival skills without subsidized resources, in which case graduation from an incubator may cause an instant negative effect on survival in the 
post-incubation period. The author points out that performance during incubation might be a good predictor of business failure after graduation and concludes that his findings do not support the presumption of sustainable and strong firm growth after incubation. This warrants attention to developing post-graduation programs.

It may be emphasized here that in the pursuit of a more credible incubation program evaluation, there is need to consider differing program objectives, program maturity, and contextual variations (Mian 1997; Clarysse et al. 2015). In the current situation, however, several prominent professional associations (iNBIA, IASP, $\mathrm{UBI}^{7}$ and others) have put together various formats for 'benchmarking best practices' for their member organizations.

\section{CONCLUSION AND FUTURE DIRECTION}

In this chapter, I have introduced key aspects of modern business incubation, emphasizing progress made in definitions, identifying emerging value additions in incubation models, use of diverse theoretical lenses to understand the incubation process, and the evaluation of incubation programs and their fit with the spatial context.

Based on the above analysis and discussion, it is now abundantly clear that business incubation has matured and is established as a distinct field of study and practice with increasing conceptual understanding, definitional clarity, an emerging theory, and developments in program assessment matrices (Hausberg and Korreck 2020; Mian and Figlioli 2019; Torun et al. 2018). Since its inception in the 1950s, the incubation concept has taken root globally and incubation programs have grown in number, influence, and variety. It is estimated that there are around 7,000 incubators, 2,000 accelerators, and well above 500 science and technology parks in the world (iNBIA 2017; Cohen et al. 2018; AURP 2018; UNESCO 2018). After more than six decades of use, study, and improvements, business incubation enjoys widespread acceptance and hence their global presence in the form of a myriad of established and newer forms of incubation models is ubiquitous (Mian and Figlioli 2019; Hausberg and Korreck 2020; Bank et al. 2017). Above all, incubation enjoys continued worldwide popularity and the discipline has professionalized with associations in all major regions and countries of the world (Mian et al. 2016; Klofsten et al. 2020). With this confidence we can address the challenges of developing effective models to address geographic, developmental, entrepreneurship training, technology, and sustainability issues, in diverse global settings and specific contexts. However, there continue to be challenges which require attention; for example, a study by Bank et al. (2017) questioned the ability of incubators in capturing knowledge intensive ideas describing them as the 'weak links' in the innovation ecosystem; and pointed out that most incubators have difficulties in securing sustainable inflows of qualified tenants over the longer term.

Today, policymakers interested in economic development, particularly through targeted technology-based entrepreneurial growth, actively pursue incubation strategies, establishing new programs with public and private investments. Therefore, depending upon the sponsor's objectives, business and technology incubators, accelerators, science parks, and other incubation mechanisms are considered preferred policy tools for seeding new and innovative ventures (Mian et al. 2016).

Therefore, with insights from the extant literature (Mian et al. 2016; Albort-Morant 
and Ribeiro-Soriano 2016; Hausberg and Korreck 2020), one can move beyond the question of why incubation mechanisms exist, to better define incubation and the underlying constructs as applied to these modern incubation policy tools. As stated earlier, there seems to be a relative clarity in understanding the differences among these mechanisms in supporting the startup cycle of innovative businesses during incubation. The definitional confusion is in fact caused by differences in the elements that comprise a particular program - sponsor's objectives, physical space, professional management, entry and exit policy, a mix of business support and professional services, networking, access to capital, and university resources (Mian et al. 2016). For example, physical space is needed for science/research parks and typical incubators, but training, mentoring, and seed capital are needed for accelerators (Cohen et al. 2018).

The incubator's spatial fit with the context has been discussed in the previous section. However, a nested view of incubation tools as bridging mechanisms embedded within a dynamic entrepreneurial ecosystem has also been explored with different levels of analyses - national, regional/state, park/incubator, and entrepreneur/team (Mian et al. 2012; Corona et al. 2006; McAdam et al. 2016; Beraldi and Havenid 2016). This work points to the appropriateness of regions treating incubation mechanisms as complementary rather than competitive, hence networks of parks, incubators and accelerators can have major contributions in creating dynamic and sustained innovation ecosystems.

Van Rijnsoever (2020) has highlighted the role of incubators as intermediaries to overcome weak network problems in modern entrepreneurial ecosystems. The author developed a theoretical model in which network development is a function of 'meeting' and 'mating' in an incubator setting and applied the insights gained to an agent-based model, which allowed for estimating how each support mechanism contributed to overcoming weak network links in a financial support network. The conclusion was that the systematic benefits of incubators also greatly enhance their societal value proposition.

In this line of inquiry, a multi-level research thread has been illustrated (Ali and D'Eredita, Chapter 11 in this Handbook) in the context of developing a resourcechallenged region with the help of a centralized downtown incubator serving as a hub of a city's entrepreneurial activity. Incubator projects, particularly in less endowed developing regions, with institutionally void environments can also serve social objectives, such as their use as a policy tool to address the problem of poverty alleviation such as in Brazil (Etzkowitz 2002; Mrkajic 2017).

Lamine et al. (2018) point out that in terms of universities and their incubators, there is a need to better integrate with regional development entities. For example, to what extent is there a need for incubators attached to universities in emerging economies to develop links with and attract expatriate and, especially, returning entrepreneurs who can provide expertise and mentoring, also involving university alumni networks in facilitating incubator firm development? This research should also take into account the variety of university types (research, teaching, agriculture, medical, etc.) within a region to avoid a mismatch with what the university can do. Studies of the use of student incubators and as pedagogy and experiential training for transforming innovative student projects into innovative ventures are on the rise (Metcalf et al. 2020; Breznitz and Zhang 2019; Mian et al. 2010). This potential must be tapped.

Bank et al. (2017) posit the use of green technology incubators, which has an important role to play in promoting environmental sustainability and propose ways to the inflow 
of tenants. Klofsten et al. (2020) highlight incubator size and specialization issues and show that size is important in achieving efficiency and networking benefits for clients, and highlight how incubators can play an important coordinating role in the formation of technology networks with diverse actors, such as researchers, scientists, students in technology, sciences and engineering, managers, policymakers, and entrepreneurs.

Pique et al. (Chapter 8 in this Handbook) suggest that the transition toward an innovative regional economy is supported by locating incubation mechanisms in well-connected larger metropolitan areas with a diverse economy, strong knowledge base, high quality of life, increased globalization of business and $\mathrm{R} \& \mathrm{D}$, cultural diversity, accessibility, and trained personnel - these are assets to attract outside firms. This, however, leads to a key policy question for governments, whether to back winners or help losers - in other words, whether to invest in already thriving regions or weaker areas.

Accelerators are highly promising, particularly as a new post-startup incubator model for providing targeted assistance over a limited period to screen business ideas, or help young firms achieve accelerated and sustained growth. While accelerators have proliferated, research on the role and efficacy of these programs is limited, providing opportunity and need for more study. Pauwels et al. (2016) offer a better understanding of the incubation process of modern accelerators through the inductive use of the design perspective for theory development. Three different accelerator archetypes are identified. This line of research requires continued attention, as there have been several recent studies exploring the acceleration concept, design, and their potential contributions to technology startups (Cohen et al. 2019; Yu 2020; Hallen et al. 2020).

To summarize, various incubator mechanisms and models discussed in this chapter are now established as successful policy tools for planned economic and social development, preferably as part of an entrepreneurship ecosystem. Future challenges lie ahead in the areas of refinement in theory, further clarity of definitions, incubator program sustainability, well-developed benchmarking matrices, insights on specialization and size, use as experiential learning tool, addressing social equity, exploration of innovative funding, and better use of digitization and emerging new technologies. However, this chapter assists in an evidence-based development and theoretical understanding, and acts as a call for further consolidation and refinement of the incubation field through authentic study and reflective practice.

\section{NOTES}

1. This chapter is based on the authors' opening presentation at the Entrepreneurship and Innovation Intermediaries PDW during the 79th Academy of Management annual conference, Boston, 2019. It includes excerpts from Mian et al. (2016). 'Technology business incubation: an overview of the state of knowledge' (with permission from Elsevier); and benefited from Mian (2014). 'Business incubation and incubator mechanisms', in A. Fayolle (ed.), Handbook of Research on Entrepreneurship, Cheltenham, UK and Northampton, MA, USA: Edward Elgar. The author is thankful to his colleagues Magnus Klofsten and Wadid Lamine for their review of the manuscript providing helpful comments. Suggestions from Henry Etzkowitz and Edward B. Roberts are also appreciated.

2. In this chapter, the terms business incubation or incubator mechanism are used interchangeably to represent all incubation models/tools including business and technology incubators, accelerators, science parks, co-working, and maker spaces, and other property-based or virtual organizations established to support new venture creation and development. However, the main focus remains on the incubator, accelerator, and science park models. 


\section{Handbook of research on business and technology incubation and acceleration}

3. IASP has recently changed its definition to include 'area of innovation' going beyond the SP as an organization.

4. In this section the focus of historic emergence of incubation is on the United States. The US, being the pioneer of modern business incubation, where science/research park, incubator and then accelerator models first emerged, has a dynamic and large incubation industry, and there is availability of data made possible by the professional organizations and researchers. However, over the last more than two decades several European countries have taken the lead in establishing incubation programs, professional organizations, and research and studies have proliferated. Other regions of the world, including several countries from Asia, Latin America, and Oceania, have also made significant progress in this field.

5. The various country and regional professional associations and universities which are the sources of information are: iNBIA - International Business Innovation Association, USA; BVIZ - Germany; RETIS - France; SISP - Sweden; MOST - Ministry of Science and Technology, China; ANPROTEC Brazil; CABI - Canadian Association of Business Incubation; IIM - Indian Institute of Management, Ahmedabad; IBA - Institute of Business Administration, Karachi; also see references.

6. This number is, however, a conservative estimate. According to the World Alliance of Innovations which is made up of 24 associations of science and technology parks there were 1,500 STPs in 2009. These facilities may include industrial parks as well. See reference.

7. University Business Incubators - Global; https://ubi-global.com/, accessed June 20, 2020.

\section{REFERENCES}

AABI (2009). Asian Association of Business Incubation, http://www.aabi.info/, accessed July 23, 2019.

Adkins, D. (2002). A Brief History of Business Incubation in the United States, Athens, OH: NBIA Publications.

Ahmad, A. (2014). A mechanisms-driven theory of business incubation. International Journal of Entrepreneurial Behavior \& Research 20(4), 375-405.

Al-Ayyash, S., McAdam, M., and O'Gorman, C. (2020), IEEE Transactions on Engineering Management, https://www.ieee.org/publications/rights/index.html, accessed March 23, 2019.

Albort-Morant, G., and Ribeiro-Soriano, D. (2016). A bibliometric analysis of international impact of business incubators. Journal of Business Research, 69(5), 1775-1789.

Amezcua, A., Grimes, M., Bradley, S., and Wiklund, J. (2013) Organizational sponsorship and founding environments: a contingency view on the survival of business incubated firms, 1994-2007. The Academy of Management Journal, 56(6), 1628-1654.

ANPROTEC, Brazilian Association of Science Parks and Incubators, https://anprotec.org.br/site/, accessed July 22, 2019.

Audretsch, D., Link, A., and Walshok, M.(2015). Introduction. In The Oxford Handbook of Local Competitiveness. Oxford and New York: OUP.

Audretsch, D., Columbelli, A., Gilli, L., Tommaso, M., and Rasmusen, E (2020). Innovative start-ups and policy initiatives, Research Policy, July, https://doi.org/10.1016/j.respol.2020.104027.

AURP (2018). Association of University Research Parks, Communities of Innovation: A State of the Practice, Perkins \& Will. https://aurp.memberclicks.net/assets/documents/aurp, accessed January 20, 2019.

Autio, E., and Klofsten, M. (1998). A comparative study of two European business incubators. Journal of Small Business Management, 36(1), 30-43.

Bank, N., Fichter, K., and Klofsten, M. (2017). Sustainability-profiled incubators and securing the inflow of tenants - The case of Green Garage Berlin. Journal of Cleaner Production, 157, 76-83.

Beraldi, E., and Havenid, M. (2016). Identifying new dimensions of business incubation: a multi-level analysis of Karolinska Institute's incubation system. Technovation, September 2015.

Barbero, J. L., Casillas, J. C., Ramos, A., and Guitar, S. (2012). Revisiting incubation performance: how incubator typology affects results. Technological Forecasting \& Social Change, 79 (5), 888-902.

Barrehag, L., Fornell, A., Larsson, G., Mårdström, V., Westergård, V., and Wrackefeldt, S. (2012). Accelerating Success: A Study of Seed Accelerators and Their Defining Characteristics. Gothenburg, Sweden: Chalmers University of Technology. Retrieved, 16 July 2020.

Bergek, A., and Norrman, C. (2008). Incubator best practice: a framework. Technovation, 28, 20-28.

Birch, D. L. (1979). The Job Generation Process, unpublished report prepared by the MIT Program on Neighborhood and Regional Change for the Economic Development Administration, US Department of Commerce, Washington, DC.

Bøllingtoft, A., and Ulhøi, J. P. (2005). The networked business incubator - leveraging entrepreneurial agency? Journal of Business Venturing, 20(2), 265-290. 
Bone, Jonathan, Allen, Olivia, and Haley, Christopher (2017). Business incubators and accelerators: the national picture, BEIS Research Paper, No. 2017/7, UK Government, Department for Business, Energy \& Industrial Strategy, London.

Breznitz, S., and Zhang, Q. (2019). Fostering the growth of student startups from university accelerators: an entrepreneurial ecosystem perspective, Industrial and Corporate Change, 28(4), 855-873.

Bruneel, J., Ratinho, T., Clarysse, B., and Groen, A. (2012). The evolution of business incubators: comparing demand and supply of business incubator services across different incubator generations. Technovation, 32, $110-121$.

BVIZ - The Federal German Association of Innovation, Technology and Business Incubation Centers, https:// www.wainova.org/project/bviz/, accessed June 17, 2020.

CABI, Canadian Association of Business Incubation, http://www.cabi.ca, accessed December 30, 2012.

Cadorin, E., Klofsten, M., and Löfsten, H. (2019). Science Parks, talent attraction and stakeholder involvement: an international study. The Journal of Technology Transfer, 1-28.

Chesbrough, H. (2017). The future of open innovation, Research-Technology Management, 60(1), 35-38, DOI: 10.1080/08956308.2017.1255054.

Clarysse, B., Wright, M., Lockett, A., Van de Velde, E., and Vohra, A. (2005). Spinning out new ventures: a typology of incubation strategies from European research institutions. Journal of Business Venturing, 20(2), $183-216$.

Clarysse, B., M. Wright, and Van Hove, J. (2015). A Look Inside Accelerators: Building Businesses. London: Nesta. Retrieved from http://www.nesta.org.uk/sites/default/files/a_look_inside_accelerators.pdf.

Clausen, T., and Rasmussen, E. (2011). Open innovation policy through intermediaries: the industry incubator program in Norway, Technology Analysis \& Strategic Management, 23(1), 75-85, DOI: 10.1080/09537325. 2011.537109.

Cohen, W., and Lavinthal, D. (1990). Absorptive capacity: a new perspective on learning and innovation, Administrative Science Quarterly, 35(1), 128-152.

Cohen, S., Bingham, C., and Hallen, B. (2018). The role of accelerator designs in mitigating bounded rationality in new ventures, Administrative Science Quarterly, July.

Cohen, S., Fehder, D., Hochberg, Y., and Murray, F. (2019). The design of startup accelerators, Research Policy, 48, 1781-1797.

Corona, L., Doutriaux, J., and Mian, S. A. (2006). Building Knowledge Regions in North America: Emerging Technology Innovation Poles, Cheltenham, UK and Northampton, MA, USA: Edward Elgar.

Dee, N., Gill, D., Weinberg, C., and McTavish, S. (2015). Startup Support Programs: What's the Difference? London: Nesta. Retrieved from http://www.nesta.org.uk/sites/default/files/whats_the_diff_wv.pdf.

Drori, I., and Wright, M. (2019). Accelerators: Characteristics, trends, and new entrepreneurial ecosystem. In M. Wright and I. Drior (eds), Accelerators: Successful Venture Creation and Growth, Cheltenham, UK and Northampton, MA, USA: Edward Elgar.

Etzkowitz, H. (2002). Incubation of incubators: innovation as a triple helix of university-industry-government networks, Science and Public Policy, 29(2), 115-128.

EU (2002). The Benchmarking of Business Incubators: Final Report, European Commission, Enterprise Directorate General, Center for Strategy and Evaluation, UK.

EU (2010). The Smart Guide to Innovation-Based Incubators (IBI), European Union Regional Policy Report (accessible at file:///C:/Users/DRF4C8 1.SAR/AppData/Local/Temp/ innovation_incubator.pdf).

EU (2013). Setting up, Managing and Evaluating EU Science and Technology Parks European Commission, Directorate-General for Regional and Urban policy, Belgium (accessible at http://ec.europa.eu/regional_ policy/sources/docgener/studies/pdf/stp report_en.pdf).

Figlioli, A., Rush, H., and Sapsed, J. (2017). The new types of innovation habitats to help startups grow and scale faster: The Digital Catapult Centers in UK. Paper presented in the British Academy of Management, 31st Annual Conference, UK.

Galbraith, B., McAdam, R., and Cross, S. (2019). The evolution of the incubator, past, present, and future. IEEE Transactions on Engineering Management, 1-7. https://doi.org/10.1109/TEM.2019.2905297.

Gans, J. S., and Stern, S. (2003). The product market and the 'market for ideas': commercialization strategies for technology entrepreneurs, Research Policy, 32(2), 333-350.

Gilani, Aziz, and Dettori, Gianluca (2011). Incubators in US and Europe - Speed and scale in capital formation. Kauffman Fellow Program. p. 21. Retrieved, 16 July 2020.

Goswami, K., Mitchell, R., and Bhagavatula, S. (2018). Accelerator expertise: understanding the intermediary role of accelerators in the development of the Bangalore entrepreneurial ecosystem. Strategic Entrepreneurship Journal, 12, 117-150.

Grimaldi, R., and Grandi, A. (2005). Business incubators and new venture creation: an assessment of incubating models. Technovation, 25, 111-121.

Guerrero, M., and Urbano, D. (2012). The development of an entrepreneurial university. Journal of Technology Transfer, 37(1), 43-74. 


\section{Handbook of research on business and technology incubation and acceleration}

Hackett, S. M., and Dilts, D. M. (2004). A systematic review of business incubation research. Journal of Technology Transfer, 29(1), 55-82.

Hallen, B., Cohen, S., and Bingham, C. (2020). Do accelerators work? If so, how? Organization Science, 31(2), 378-414. https://doi.org/10.1287/orsc.2019.1304.

Hansen, M. T., Chesbrough, H. W., Nohria, N., and Sull, D. N. (2000). Networked incubators. Harvard Business Review, 78, 5, 74-84.

Harper-Anderson, E., and Lewis, D. (2017). What makes business incubation work? Measuring the influence of incubator quality and regional capacity on incubator outcomes, Economic Development Quarterly, 1-18.

Hathaway, I. A. (2016). Accelerating growth: Startup accelerator programs in the United States, February 17, 2016, Washington, DC, The Brookings Institution. Available at:_https://www.brookings.edu/research/ accelerating-growth-startup-accelerator-programs-in-the-united-states/, accessed July 16, 2020.

Hausberg, P. J., and Korreck, S. (2020). Business Incubators and accelerators: a co-citation analysis-based, systematic literature review. Journal of Technology Transfer, 40, 151-176.

Heinemann, F. (2015). Corporate Accelerator Database, https://corporate-accelerators.net/database/index. html, accessed June 17, 2020.

Hochberg, Y. (2016). Accelerating entrepreneurs and ecosystems: the seed accelerator model. Innovation Policy, and the Economy, 16(1), 25-51.

IASP (2015). International Association of Science Parks and Areas of Innovation at https://www.iasp.ws, accessed July 16, 2020.

IBA, Institute of Business Administration, Karachi, https:/www.iba.edu.pk/, accessed June 20, 2020.

iNBIA (2017). International Business Innovation Association, accessible at https://www.inbia.org/, accessed July $17,2020$.

IIMA, Indian Institute of Management, Ahmedabad, https://www.iima.ac.in/, accessed June 20, 2020.

Ketchen, D. J., Thomas, J. B., and Snow, C. C. (1993). Organizational configurations and performance: a comparison of theoretical approaches. Academy of Management Journal, 36, 1278 -1313.

Kirchhoff, B. A. (1994). Entrepreneurship and Dynamic Capitalism: The Economics of Business Firm Formation and Growth. Westport, CT: Praeger.

Klofsten, M., Lundmark, E., Wennberg, K., and Bank, N. (2020). Incubator specialization and size: divergent paths towards operational scale. Technological Forecasting and Social Change, 157, 76-83.

Lamine, W., Mian, S., Fayolle, A., Wright, M., Klofsten, M. and Etzkowitz, H. (2018). Technology business incubation mechanisms and sustainable regional development. The Journal of Technology Transfer, 43(5), $1121-1141$.

Link, A., and Scott, J. T. (2003). U.S. science parks: the diffusion of an innovation and its effects on the academic missions of universities. International Journal of Industrial Organization, 21, 1323-1356.

Link, A., and Scott, J. (2015). Research, science, and technology parks: vehicles for technology transfer. In A. Link, D. Siegel, and M. Wright (eds), The Chicago Handbook of University Technology Transfer, Chicago and London: University of Chicago Press, 168-187.

McAdam, M., and McAdam, R. (2008). High tech start-ups in University Science Park incubators: the relationship between the start-up's lifecycle progression and use of the incubator's resources. Technovation, 28(5), 277-290.

McAdam, M., Miller, K., and McAdam, R., (2016). Situated regional university incubation: a multi-level stakeholder perspective. Technovation, 50-51.

Messeghem, K., and Sammut, S. (2014). Thirty years of research in entrepreneurial support, Editorial. Int. J. Entrepreneurship and Small Business, 23(4), 2014.

Messeghem, K., Bakkali, C., Sammut, S., and Swalhi, A. (2017). Measuring nonprofit incubator performance: toward an adapted balanced scorecard approach. Journal of Small Business Management, 56(10), 658-680.

Metcalf, L. E., Katona, T. M., and York, J. L. (2020). University startup accelerators: startup launchpads or vehicles for entrepreneurial learning? Entrepreneurship Education and Pedagogy. https://doi.org/10.11 $77 / 2515127420931753$.

Mian, S. (1996). Assessing value-added contributions of university technology business incubators to tenant firms. Research policy, 25(3), 325-335.

Mian, S. (1997). Assessing and managing the university technology business incubator: an integrative framework. Journal of Business Venturing, 12(4), 251-285.

Mian, S. (2011). University's involvement in technology business incubation: what literature and practice tell us? International Journal of Entrepreneurship and Innovation Management, 13(2), 113-121.

Mian, S. (2014a). Business incubation and incubator mechanisms. in A. Fayolle (ed.), Handbook of Research on Entrepreneurship, Cheltenham, UK and Northampton, MA, USA: Edward Elgar, pp. 335-366.

Mian, S. (2014b). Business incubation mechanisms and new venture support: emerging structures of US science parks and incubators. International Journal of Entrepreneurship and Small Business, 23(4), 419-435.

Mian, S. and Figlioli, A. (2019). Traditional and Emerging Models of Entrepreneurship and Innovation Intermediaries (Incubators, Accelerators, Innovation Centers/Habitats/Hubs, Science/Research Parks and 
Areas of Innovation): Some Definitional Challenges. Presentation in the Academy of Management Annual Meeting 2019, ENT Division PDW, \#18501.

Mian, S., and Plosila, W. (2011). Science and technology based regional entrepreneurship in the united states: the evolution of national and state policies and programs. In S. Mian. (ed). Science and Technology Based Regional Entrepreneurship: Global Experience in Policy and Program Development, Cheltenham, UK and Northampton, MA, USA: Edward Elgar Publishers, pp. 19-46.

Mian, S., Corona, L., and Doutriaux, J. (2010). Building knowledge regions in developing nations with emerging innovation infrastructure: evidence from Mexico and Pakistan. International Journal of Innovation and Regional Development, 2(4), 304-330.

Mian, S., Fayolle, A., and Lamine, W. (2012). Building sustainable regional platforms for incubating science and technology businesses: evidence from US and French science and technology parks. International Journal of Entrepreneurship and Innovation, 13(4), 235-247.

Mian, S., Lamine, W., and Fayolle, A. (2016). Technology business incubation: an overview of the state of knowledge. Technovation, 50-51, 1-12.

Mian, S., Doutriaux, J., and Corona, L. (2020). The Role of Location and Context in the Success of Formal Incubation Mechanisms: Evidence from the Emerging North American Regions, working paper, School of Business, State University of New York, Oswego, NY 13126.

Mrkajic, B. (2017). Business incubation models and institutionally void environments. Technovation, 68, 44-55.

Nowak, M. J., and Grantham, C. E. (2000). The virtual incubator: managing human capital in the software industry. Research Policy, 29, 125-134.

Patton, D., Warren, L., and Bream, D. (2009). Elements that underpin high-tech business incubation processes. Journal of Technology Transfer, 34, 621-636.

Pauwels, C., Clarysse, B., Wright, M., and Van Hove, J. (2016). Understanding a new generation incubation model: the accelerator. Technovation, 50-51, 13-24.

Petrucci, F. (2018). The incubation process of mid-stage startup companies: a business network perspective. Industrial Marketing and Purchasing (IMP) Journal, 12(3), 544-566, https://doi.org/10.1108/ IMP-07-2017-0043.

Phan, P. H., Siegel, D. S., and Wright, M. (2005). Science parks and incubators: observations, synthesis, and future research. Journal of Business Venturing, 20(2), 165-182.

Plosila, W., and Allen, D. N. (1985). Small business incubators and public policy: implications for states and local development strategies. Policy Studies Journal, 13, 729-734.

Retis, French National Innovation Network, https://en.retis-innovation.fr/, accessed July 30, 2019

Rice, M. (2002). Co-production of business assistance in business incubators. an exploratory study. Journal of Business Venturing, 17, 163-187.

Roberts, E. (1991). Entrepreneurs in High Technology: Lessons from MIT and Beyond, Oxford: Oxford University Press, pp. 33-34.

Rose, D., and Grof, M. (2017). The State of the Startup Accelerator Industry 2016, Gust and Fundacity, https:// www.forbes.com/sites/groupthink/2016/06/29/the-state-of-the-startup-accelerator-industry/\#26fe44437b44, accessed July 15, 2020.

Rothaermel, F. T., and Thursby, M. (2005). University-incubator firm knowledge flows: assessing their impact on incubator firm performance. Research Policy, 34, 305-320.

Schwartz, M. (2011). Incubating an illusion? Long-term incubator firm performance after graduation. Growth and Change, 42(4), 491-516.

Sherman H., and Chappell, D. (1998). Methodological challenges in evaluating business incubator outcomes. Economic Development Quarterly, 12(4), 313-321.

SISP, Swedish Science Parks and Incubators Association, https://www.sisp.se/, accessed August 23, 2010.

Siegel, D. S., Westhead, P., and Wright, M. (2003). Science parks and the performance of new technology-based firms: a review of recent u.k. evidence and an agenda for future research. Small Business Economics, 20(2), 177-184.

Smilor, R., and Gill, M. (1986). The New Business Incubator: Linking Talent, Technology, Capital, and Know-how. Lexington, MA: Lexington Books.

Soetanto, D., and Jack, S. (2016). The impact of university-based incubation support on the innovation strategy of academic spin-offs. Technovation, 50-51, 25-40.

Todorovic, Z.W. and Moenter, K. (2010). Tenant firm progression within an incubator: progression toward an optimal point of resource utilization. Academy of Entrepreneurship Journal, 16(1), 23-40.

Torun, M., Peconick, L., Sobreiro, V., and Kimura, H. (2018). Assessing business incubation: a review on benchmarking, International Journal of Innovation Studies, 2(3), 91-100.

Tötterman, H., and Sten, J. (2005). Start-ups business incubation and social capital. International Small Business Journal, 23(5), 487-511.

UNESCO (2018). Science Parks around the World. Paris: United Nations Educational, Scientific and Cultural 


\section{Handbook of research on business and technology incubation and acceleration}

Organization. Available at http://www.unesco.org/new/en/natural-sciences/sciencetechnology/university-indu stry-partnerships/science-parks-around-the-world/, accessed July 14, 2020.

Van de Ven, A. (1989). Nothing is quite so practical as a good theory. Academy of Management Review, 14(4): https://doi.org/10.5465/amr.1989.4308370.

Van Rijnsoever, F. J. (2020). Meeting, mating, and intermediating: how incubators can overcome weak network problems in entrepreneurial ecosystems. Research Policy, 49, 1-15.

Vedovello, C. (1997). Science parks and university-industry interaction: geographical proximity between the agents as a driving force. Technovation, 17, 491-502.

Voisey, P., Gornall, L., Jones, P., and Brychan, T. (2006). The measurement of success in a business incubation project. Journal of Small Business and Enterprise Development, 13, 454-468.

WAINOVA (2009). Wainova Atlas of Innovation: Science/Technology/Research Parks and Business Incubators in the World. Cheshire: Ten Alps Publishing.

Warren, L., Patton, D., and Bream, D. (2009). Knowledge acquisition processes during the incubation of new high technology firms. International Entrepreneurial Management Journal, 5, 481-495.

Weiblen, T., and Chesbrough, H. (2015). Engaging with startups to enhance corporate innovation. California Management Review, 57(2), 66-90.

$\mathrm{Yu}, \mathrm{S}$. (2020). How do accelerators impact the performance of high-technology ventures? Management Science, 66(2), 530-552. https://doi.org/10.1287/mnsc.2018.3256. 